\title{
Estimations of Polycyclic Aliphatic Hydrocarbon and Total Petroleum Hydrocarbon in Aquatic Faunas Found in Foccardos Terminal River in Port Harcourt, Rivers State
}

\author{
Oparaji EH, Nweze EJ, Agbo KU, Arinzechukwu EO, Anosike JC and Arazu AV* \\ Department of Biochemistry, University of Nigeria, Nsukka, Enugu State, Nigeria
}

\begin{abstract}
Increasing water bodies and water inhabitants' pollution has posed a great global concern as aquatic animals are continually endangered with effluents from various sources. Polycyclic aliphatic hydrocarbons are Poly Nuclear Aliphatic Hydrocarbons and organic matter without fused ring and contains hydrogen and carbons invariably with or without substituent attached to it, Total Petroleum Hydrocarbon (TPH) is a term used to describe a large family of several hundred chemical compounds that originally come from crude oil. In this study, Petroleum hydrocarbons such as Petroleum Aliphatic Hydrocarbon (PAHs) and Total petroleum hydrocarbons (TPHs) were analyzed for in the seven sampled aquatic animals using Gas Chromatographic technique. Petroleum Aliphatic Hydrocarbons attained higher concentrations in $n$-hexadecane, tetracosane and tetradecane with concentration values of $0.49 \pm 0.29,0.59 \pm 0.94$ and $0.97 \pm 0.64 \mathrm{mg} / \mathrm{kg}$ respectively. It was found in this study that even chain aliphatic hydrocarbons were found in all the samples and dominated the odd chains aliphatic hydrocarbons. Heavy weight Aliphatic Hydrocarbons like hexacosane and triaconane were not detected in all the tested aquatic animals as Octacosane was found in only three of the aquatic animals while hexatricontane was found in only one of the samples. Odd chain aliphatic hydrocarbons like Nonane and Nonadecane attained their highest concentrations of $0.19 \pm 0.15$ and $0.33 \pm 0.45 \mathrm{mg} / \mathrm{kg}$ respectively. It was gathered from the results of this experiment that Total Petroleum Hydrocarbons (TPH) is greater than the aliphatic petroleum hydrocarbons in all the tested aquatic faunas from the Forcados River. TPH and TAH recorded maximum concentrations of $3.64 \pm 0.94$ and $3.46 \pm 0.91 \mathrm{mg} / \mathrm{kg}$ respectively
\end{abstract}

Keywords: TAHs; TPHs; Aquatic animals

\section{Introduction}

Enormous quantities of noxious pollutants are continually released into marine ecosystem over the last few decades. Among these pollutants, petroleum hydrocarbons represent the major pollutants of marine environment $[1,2]$. In view of this, aquatic ecosystem is constantly challenged with hydrocarbons of different compositions and origin. During exploration, production, refining, transport and storage of petroleum and petroleum products, some accidental spills may occur [3]. The threat of petroleum pollution not only from natural sources such as seeps but also from anthropogenic activities such as spillages from effluent treatment plants and other emissions, endangers the marine biodiversity [1,3]. Marine organisms tends to accumulate different dietary and waterborne contaminants including heavy metals, polycyclic aromatic hydrocarbon and other petroleum products mixed with organic compound such as Anthracene etc (Total Petroleum Hydrocarbon) from the environment which they live in [4-7]. Over the years, oil companies and their allied located mostly in the Niger Delta region in Nigeria have generated myriad of pollutants in the form of gaseous emissions, oil spills, effluents and solid wastes [8,9] that have polluted the marine environment beyond sustainability. Heightened navigational activities in inland and coastal waters of the Niger Delta are other anthropogenic sources of refined petroleum pollution to the aquatic environment [10]. An investigation of the Polycyclic Aromatic Hydrocarbon (PAHs) concentrations in some Niger Delta sediment carried out by Ezemoye and Ezemoye revealed an elevated level of these pollutants in the sediments studied. With the increasing human population there has been increased need for food supply. This with the need for quality sea food protein has increased the demand for sea foods e.g., fish and its products [11].

The global consumption of fish and derived fish products for example has generally increased during recent decades [12]. The cage aquaculture sector has grown very rapidly during the past 20 years and is currently undergoing rapid changes in response to pressures from globalization and growing demand for aquatic products in both developing and developed countries [11]. Most aquatic faunas (fish) enjoy a good reputation as a nutritious and healthy food; this is because they are good sources of omega- 3 fatty acids which have been associated with health benefits due to its cardio-protective effects [12].

However, the levels of contaminants in aquatic faunas and poor management of sea foods are of particular interest because of the potential risk to humans who consume them. High level of petroleum hydrocarbons (PAHs and TPH) can accumulate in aquatic faunas to such a degree that it becomes toxic to humans when ingested. In Nigeria, data on TAHs and TPHs in both aquaculture area and cultured organism are lacking. The safety and health state of the sea foods consumed are not aware of. Studies on the presence of petroleum hydrocarbons (TAHs and $\mathrm{TPH})$ in the aquatic/aquaculture environment are important because they play toxic roles in aquatic faunas especially when they passed on to human beings through the consumption of fish and fish products.

Within the tropics geographical region, reliable information on pollutants prevalence and concentrations in aquatic animals as they

*Corresponding author: Arazu AV, Department of Biochemistry, University of Nigeria, Nsukka, Enugu State, Nigeria, Tel: +23659588154; E-mail: vivianarazu@yahoo.com

Received July 21, 2017; Accepted October 24, 2017; Published October 29, 2017

Citation: Oparaji EH, Nweze EJ, Agbo KU, Arinzechukwu EO, Anosike JC, et al. (2017) Estimations of Polycyclic Aliphatic Hydrocarbon and Total Petroleum Hydrocarbon in Aquatic Faunas Found in Foccardos Terminal River in Port Harcourt Rivers State. J Environ Anal Toxicol 7: 519. doi: 10.4172/2161-0525.1000519

Copyright: ( 2017 Oparaji EH, et al. This is an open-access article distributed under the terms of the Creative Commons Attribution License, which permits unrestricted use, distribution, and reproduction in any medium, provided the original author and source are credited. 
Citation: Oparaji EH, Nweze EJ, Agbo KU, Arinzechukwu EO, Anosike JC, et al. (2017) Estimations of Polycyclic Aliphatic Hydrocarbon and Total Petroleum Hydrocarbon in Aquatic Faunas Found in Foccardos Terminal River in Port Harcourt, Rivers State. J Environ Anal Toxicol 7: 519. doi: 10.4172/2161-0525.1000519

Page 2 of 5

serve as most food within tropics are lacking; in thereof, this present study was designed to provide more information in addition to the existing ones on the status of contamination in aquatic animals and also in promulgation of laws guiding anthropogenic activities, oil spills in Foccardoes terminal river in PortHarcourt Rivers state.

\section{Materials and Methods}

\section{Study area}

Samples were collected from the Forcardoes terminal rivers Portharcourt, Rivers state. Forcados terminal rivers have the highest number of brackishwater cages and since it's located within the exploring sites of most oil industries in Rivers state, it's said to be the most vulnerable rivers in River state [10] receiving most of the effluents from the activities of the oil industries.

\section{Sample and sampling period}

Sampling was conducted twice throughout the study period. Samples collected were water and Fish using PVC tube and fishing net respectively as described in [13].

Determination of polycyclic aliphatic hydrocarbons: This was carried out through solvent extraction and chromatographic analysis (Gas chromatography) as described by Retnam and Zakaria.

Aquatic fauna (fish) sample extraction procedures: This was also carried out by the method as described by Retnam and Zakaria. This method measures the collective concentrations of extractable aliphatic and petroleum hydrocarbons in fish samples. Aliphatic hydrocarbons are quantitated within ranges $\mathrm{C} 9$ through $\mathrm{C} 18$ and $\mathrm{C} 19$ through C36. In the extraction process, an equimolar solvent containing a mixture of 50:50 mix of acetone and methylene chloride was prepared. An aliquot of 10 grams of well-mixed sample was measured into a solvent rinsed beaker. A total volume of $50 \mathrm{ml}$ of the solvent mix was also added into the samples spiked with $1 \mathrm{ml}$ of the surrogate mix. The sample was inside the sonicator and was sonicated for about 10-15 minutes at about $700^{\circ} \mathrm{C}$. A mass up to $10 \mathrm{~g}$ of anhydrous sodium sulphate was added into the sample until a clear extract develops. The extract solvent was poured into a round bottom flask.

The processes were repeated once more with an additional $50 \mathrm{ml}$ of solvent mix, sonicated and the beaker was allowed to settle and it's been decanted into the same round bottom flask. The solvents were concentrated using $n$-hexane exchange and also re-concentrated to 1:3 $\mathrm{ml}$ volume. The sample was fractionated into the aliphatic and aromatic fractions using the silica gel columns. The column was packed with $10 \mathrm{~g}$ of 100-200-mesh silica gel pre-conditioned (baked) at $105^{\circ} \mathrm{C}$ overnight. The silica was mixed with hexane initially to form slurry.

Total petroleum hydrocarbons: This was carried out through solvent extraction and chromatographic analysis (Gas chromatography) as detailed above as described by Retnam and Zakaria.

\section{Gas chromatographic procedure/analysis}

For polycyclic aliphatic hydrocarbon: The detector type used in this analysis is the Flame Ionization Detector (DFID).

Temperature Program: The initial temperature was set at $60^{\circ} \mathrm{C}$ with an initial time of $00 \mathrm{~s}$.

The sample ramp rate was at $1: 8^{\circ} \mathrm{C} / \mathrm{min}$ to a final temperature of a temperature $300^{\circ} \mathrm{C}$ held for 10 minutes. The temperature of the injector was at $250^{\circ} \mathrm{C}$ while the detector's temperature was at $300^{\circ} \mathrm{C}$.

\section{General working working procedures}

Initial Temp: $60^{\circ} \mathrm{C}$, Initial Time mins, Rate $1: 8^{\circ} \mathrm{C} / \mathrm{min}$, Final Temp: $300^{\circ} \mathrm{C}$, Final Time: 10 min Injector: $250^{\circ} \mathrm{C}$, Detector: $300^{\circ} \mathrm{C}$, Detector Type: FID.

Sample analysis for Total Petroleum Hydrocarbon (TPH): Instrument set up. The basic Gas Chromatography parameters for the analysis of Total Petroleum Hydrocarbon are as follows:

The Injector Temperature was set at a temperature of $250^{\circ} \mathrm{C}$, while the detector temperature was at $300^{\circ} \mathrm{C}$. Equilibrium Time of the experiment was at 0.1 seconds throughout the experiment. Oven Temp was at $60^{\circ} \mathrm{C}$ with an initial value also at $60^{\circ} \mathrm{C}$. The samples were ramp at the rate of $1: 10^{\circ} \mathrm{C} / \mathrm{min}$ with an initial time of 2 minutes until an intermediary temperature value of $300^{\circ} \mathrm{C}$ Was obtained held 10 minutes. The samples were ramp at the rate of $2: 25^{\circ} \mathrm{C} / \mathrm{min}$ until a final temperature value of $310^{\circ} \mathrm{C}$ held for 3 minutes final time with the Purge /Valve on 1 minute.

\section{Outlook of the working procedures}

Injector Temp: $250^{\circ} \mathrm{C}$, Detector Temp: $300^{\circ} \mathrm{C}$, Equilibruim time: 0.1, Oven Temp: $60^{\circ} \mathrm{C}$, Initial value: $60^{\circ} \mathrm{C}$, Initial Time: 2 minutes, Rate 1: $10^{\circ} \mathrm{C} / \mathrm{min}$, Intermediate Value: $300^{\circ} \mathrm{C}$, Time: 10 mins, Rate $2: 25^{\circ} \mathrm{C} /$ min, Final Value: $310^{\circ} \mathrm{C}$, Final time: 3 minutes, Purge /Valve On 1 minute.

\section{Statistical analysis}

One-way ANOVA test were used to evaluate the significant difference in the concentration of different studied polycyclic aliphatic hydrocarbons and Total petroleum hydrocarbon with respect to the fish from Forcadoes Terminal River. A probability at level of 0.05 or less was considered significant. Standard errors were also estimated [14].

\section{Results}

Aliphatic Hydrocarbon Concentrations $(\mathrm{Mg} / \mathrm{kg})$ in Aquatic Faunas from Forcadoes Terminal Rivers, Portharcourt, Rivers State (Figure 1).

Total Petroleum Hydrocarbon Concentrations (TPH), Total Aliphatic Hydrocarbon (TAH), Polynuclear Aromatic Hydrocaron $(\mathrm{Mg} / \mathrm{kg}$ ) in Aquatic Faunas from Forcadoes Terminal Rivers, Portharcourt, Rivers state (Table 1).

The Table 2 shows the sequences of total petroleum hydrocarbons accumulation in the seven (7) aquatic faunas got from Forcadoes terminal rivers that where analyzed for.

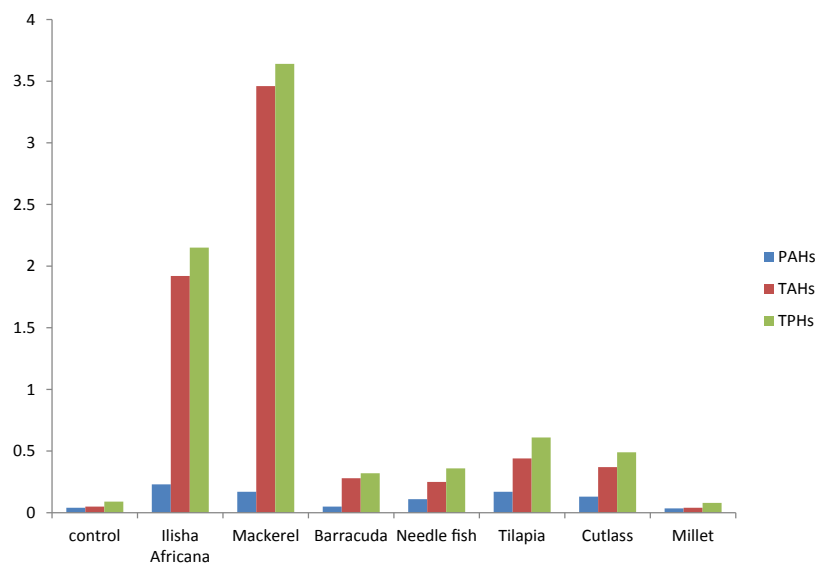

Figure 1: Total petroleum hydrocarbon concentrations in the aquatic faunas from Forcadoes terminal rivers, Portharcourt, Rivers state. 
Citation: Oparaji EH, Nweze EJ, Agbo KU, Arinzechukwu EO, Anosike JC, et al. (2017) Estimations of Polycyclic Aliphatic Hydrocarbon and Total Petroleum Hydrocarbon in Aquatic Faunas Found in Foccardos Terminal River in Port Harcourt, Rivers State. J Environ Anal Toxicol 7: 519. doi: $10.4172 / 2161-0525.1000519$

Page 3 of 5

\begin{tabular}{|c|c|c|c|c|c|c|c|c|}
\hline Aliphatic hydrocarbon & Control & llisha Africana & Mackerel & Barracuda & Needlefish & Tilapia fish & Cutlass fish & Millet \\
\hline Nonane $(\mathrm{mg} / \mathrm{Kg})$ & $0.002 \pm 0.00^{\mathrm{a}}$ & ND & $0.19 \pm 0.15^{b}$ & $0.012 \pm 0.00^{\mathrm{a}}$ & $0.011 \pm 0.00^{a}$ & $0.01 \pm 0.01^{\mathrm{a}}$ & $0.01 \pm 0.00^{a}$ & $0.002 \pm 0.00^{\mathrm{a}}$ \\
\hline Decane $(\mathrm{mg} / \mathrm{Kg})$ & ND & $0.23 \pm 0.20^{\mathrm{b}}$ & $0.27 \pm 0.09^{b}$ & $0.003 \pm 0.00^{a}$ & $0.004 \pm 0.00^{a}$ & $0.004 \pm 0.00^{a}$ & $0.013 \pm 0.01^{a}$ & $0.001 \pm 0.00$ \\
\hline Dodecane (mg/Kg) & $0.005 \pm 0.00^{\mathrm{a}}$ & $0.29 \pm 0.39^{a}$ & $0.22 \pm 0.16^{a}$ & $0.018 \pm 0.018^{a}$ & $0.004 \pm 0.00^{a}$ & $0.16 \pm 0.20^{a}$ & $0.03 \pm 0.01^{\mathrm{a}}$ & ND \\
\hline Tetradecane $(\mathrm{mg} / \mathrm{Kg})$ & $0.004 \pm 0.00^{a}$ & $0.09 \pm 0.15^{b}$ & $0.97 \pm 0.64^{b}$ & $0.01 \pm 0.00^{\mathrm{b}}$ & $0.01 \pm 0.00^{b}$ & $0.06 \pm 0.07^{b}$ & $0.03 \pm 0.02^{b}$ & $0.006 \pm 0.00^{\mathrm{a}}$ \\
\hline Hexadecane $(\mathrm{mg} / \mathrm{Kg})$ & $0.01 \pm 0.01^{\mathrm{a}}$ & $0.49 \pm 0.29^{b}$ & $0.09 \pm 0.07^{a}$ & $0.03 \pm 0.00^{\mathrm{a}}$ & $0.02 \pm 0.01^{\mathrm{a}}$ & $0.13 \pm 0.06^{\mathrm{a}}$ & $0.03 \pm 0.03^{a}$ & $0.012 \pm 0.01^{\mathrm{a}}$ \\
\hline Octadecane (mg/Kg) & $0.005 \pm 0.00^{\mathrm{a}}$ & $0.15 \pm 0.15^{\mathrm{a}}$ & $0.16 \pm 0.16^{b}$ & $0.03 \pm 0.00^{a}$ & $0.02 \pm 0.01^{a}$ & $0.01 \pm 0.01^{a}$ & $0.01 \pm 0.00^{a}$ & $0.002 \pm 0.00^{\mathrm{a}}$ \\
\hline Nonadecane $(\mathrm{mg} / \mathrm{Kg})$ & $0.006 \pm 0.01 \mathrm{a}$ & $0.25 \pm 0.42^{a}$ & $0.33 \pm 0.45^{a}$ & $0.01 \pm 0.01^{\mathrm{a}}$ & $0.01 \pm 0.01^{\mathrm{a}}$ & $0.007 \pm 0.00^{a}$ & $0.001 \pm 0.00^{a}$ & $0.002 \pm 0.00^{\mathrm{a}}$ \\
\hline Eicosane (mg/Kg) & $0.008 \pm 0.01^{\mathrm{a}}$ & $0.22 \pm 0.19^{b}$ & $0.15 \pm 0.17^{\mathrm{a}}$ & $0.02 \pm 0.01^{\mathrm{a}}$ & $0.014 \pm 0.00^{a}$ & $0.005 \pm 0.00^{a}$ & $0.004 \pm 0.00^{a}$ & ND \\
\hline Docosane $(\mathrm{mg} / \mathrm{Kg})$ & $0.006 \pm 0.01^{\mathrm{a}}$ & $0.15 \pm 0.14^{\mathrm{a}}$ & $0.35 \pm 0.20^{\mathrm{b}}$ & $0.01 \pm 0.01^{a}$ & $0.01 \pm 0.00^{\mathrm{a}}$ & $0.11 \pm 0.14^{\mathrm{a}}$ & $0.03 \pm 0.04^{a}$ & $0.004 \pm 0.00^{\mathrm{a}}$ \\
\hline Tetracosane $(\mathrm{mg} / \mathrm{Kg})$ & $0.002 \pm 0.00^{a}$ & BDL & $0.59 \pm 0.94^{b}$ & $0.09 \pm 0.05^{b}$ & $0.09 \pm 0.08^{b}$ & $0.07 \pm 0.12^{b}$ & $0.16 \pm 0.28^{b}$ & $0.012 \pm 0.00^{\mathrm{a}}$ \\
\hline Hexacosane $(\mathrm{mg} / \mathrm{Kg})$ & ND & ND & ND & ND & ND & ND & ND & ND \\
\hline Octacosane (mg/Kg) & ND & ND & $0.14 \pm 0.24$ & $0.04 \pm 0.01$ & $0.03 \pm 0.01$ & ND & ND & ND \\
\hline Triacontane $(\mathrm{mg} / \mathrm{Kg})$ & ND & ND & ND & ND & ND & ND & ND & ND \\
\hline Hexatricontane $(\mathrm{mg} / \mathrm{Kg})$ & ND & ND & ND & ND & ND & ND & $0.07 \pm 0.08$ & ND \\
\hline
\end{tabular}

Key: Values are presented as mean \pm S.D of triplicate determinations; Values with different superscript letters differs significantly $(P<0.05)$ from the control group; ND - Not Detected

Table 1: Mean Values of Aliphatic Hydrocarbons Concentrations in the Various Aquatic Faunas Isolated from Forcadoes Terminal River, Portharcourt, Rivers State.

\begin{tabular}{|c|c|c|}
\hline Sample Identity & TAH $(\mathbf{m g} / \mathbf{K g})$ & TPH $(\mathbf{m g} / \mathbf{K g})$ \\
\hline Control & $0.05 \pm 0.04$ & $0.09 \pm 0.03$ \\
\hline Ilisha Africana & $1.92 \pm 0.34$ & $2.15 \pm 0.42$ \\
\hline Mackerel & $3.46 \pm 0.91$ & $3.64 \pm 0.94$ \\
\hline Barracuda & $0.28 \pm 0.11$ & $0.32 \pm 0.12$ \\
\hline Needle fish & $0.25 \pm 0.09$ & $0.36 \pm 0.07$ \\
\hline Tilapia fish & $0.44 \pm 0.26$ & $0.61 \pm 0.24$ \\
\hline Cutlass fish & $0.37 \pm 0.25$ & $0.49 \pm 0.28$ \\
\hline Millet & $0.04 \pm 0.02$ & $0.08 \pm 0.01$ \\
\hline
\end{tabular}

Table 2: Mean Values of Total Petroleum Hydrocarbon Concentrations (TPH), Total Aliphatic Hydrocarbon (TAH) Concentrations in the Various Aquatic Faunas Isolated from Forcadoes Terminal River, Portharcourt, Rivers State.

\section{Discussion}

\section{Aliphatic petroleum hydrocarbon}

From this results in thereof it is seen that relatively the lighter members (in carbon contents) of the hydrocarbon homologous series predominates in almost the aquatic faunas that were analyzed. Aliphatic hydrocarbons ranging from 10-20 ranges are accumulated by the aquatic animals that were analyzed for, while the heavier members of the homologous family were not detected in almost all the sampled fauna species. [11] reported the same trend in their experiment as they explained that lower chain hydrocarbons crept in their way into the systems of living organisms faster than the heavy cyclic hydrocarbons. They went further to say that lighter chain hydrocarbons complex with foods of aquatic animals and as such are ingested during feeding by these sea animals. Even chain aliphatic compound like decane attained the highest concentration in mackerel fish $(0.97 \mathrm{mg} / \mathrm{kg} \pm 0.64)$ than all the assayed aliphatic hydrocarbons and showed a significant different at $p<0.05$ from the control experiment. During crude oil cracking, most effluent from the process i.e., petrochemical fractions are mostly unsaturated compounds of ethene in polyvinyl compounds, butane and decanes in the values of even factorials are predominant [15]. Other even chain aliphatic hydrocarbons like dodecane and octadecane attained significant concentrations in all the aquatic samples. Decane was detected in all the aquatic samples with maximum concentration found in Mackerel fish with a concentration of $0.27 \pm 0.09 \mathrm{mg} / \mathrm{kg}$ and significantly varied $(\mathrm{p}<0.05)$ from other samples but indifferent when compared to decane concentration in illisha Aficana fish. Its lowest concentrations were detected in Tilapia and Needle fish with a concentration of $0.004 \pm 0.00$ and not significantly different from each other $(\mathrm{p}>0.05)$. dodecane attained its highest concentrations in

Ilisha Africana and Mackerel with concentrations of $0.29 \pm 0.39$ and $0.22 \pm 0.16$ respectively which not significantly different at $\mathrm{p}>0.05$ from each other and when compared with the control experiment. in a compendium by Ronald Eisler on hydrocarbon accumulations, he reported that most bio accumulated hydrocarbons from spills and anthropogenic activities are mostly with hydrocarbons with carbon numbers $>10$ and not more than 15 carbons hydrocarbons i.e., from decane upwards to pentadecane. Other samples analysed for dodecane shows no significant different from each other at $\mathrm{p}>0.05$ while dodecane is not detected in millet fish. Hexadecane when analysed shows highest accumulation in Ilisha Africana and Tilapia Fish with concentrations of $0.49 \pm 0.29$ and $0.13 \pm 0.06$ respectively and are significantly varied from each other at $p<0.05$, while hexadecane concentrations in Ilisha fish varied from the control experiment $(\mathrm{p}<0.05)$ hexadecane in Tilapia fish shows non variability when compared with the control experiment $(p>0.05)$. Octadecane shows its highest concentration in Mackerel fish and Ilisha Aficana with concentrations of $0.16 \pm 0.16$ and $0.15 \pm$ 0.15 respectively, they shows significant variability from each other at $p<0.05$. Octadecane in Ilisha Africana fish shows non-significant variability from the control experiment at $p>0.05$ while octadecane in Mackerel fish shows significant variability from the control experiment at $\mathrm{p}<0.05$. Other sampled aquatic animal analysed for octadecane shows no significant variability from the control experiment $(\mathrm{p}>0.05)$. Other heavier even chain aliphatic hydrocarbon were also detected in the aquatic samples. Eicosane attained its highest concentration in Ilisha Aficana fish $0.22 \mathrm{mg} / \mathrm{kg} \pm 0.19$ with a significant variability $\mathrm{p}<0.05$ from the control experiment and in Mackerel fish with a concentration of $0.15 \mathrm{mg} / \mathrm{kg} \pm 0.17$ and significantly invariable $(\mathrm{p}>0.05)$ from the control experiment. Other aquatic animals i.e., Barracuda, Cutlass, Needle and Tilapia fish analysed for Eicosane shows no significant variability p $>0.05$ from the control experiment. While no eicosane was detected in Millet fish. Docosane also attain its highest concentrations in Mackerel and Illisha fish with concentrations of $0.35 \mathrm{mg} / \mathrm{kg} \pm 0.20$ and $0.15 \mathrm{mg} /$ $\mathrm{kg} \pm 0.14$ respectively. While Docosane in Mackerel shows a significant different variability $\mathrm{p}<0.05$ from the control experiment and from other analysed aquatic animals. While docosane in Ilisha Africana shows no significant variability $\mathrm{p}>0.05$ from the control experiment and from other analysed aquatic samples i.e., Barracuda, Cutlass, Needle, Tilapia and Millet fish. Tetracosane analysed for in the aquatic animals shows its highest concentrations in Mackerel fish $0.59 \mathrm{mg} / \mathrm{kg} \pm 0.94$ and significantly varied $(\mathrm{p}<0.05)$ from the control experiment also from other analysed aquatic animal. Docosane attained a concentration of $0.16 \mathrm{mg} / \mathrm{kg} \pm 0.28$ in cutlass fish which is not significant different 
Citation: Oparaji EH, Nweze EJ, Agbo KU, Arinzechukwu EO, Anosike JC, et al. (2017) Estimations of Polycyclic Aliphatic Hydrocarbon and Total Petroleum Hydrocarbon in Aquatic Faunas Found in Foccardos Terminal River in Port Harcourt, Rivers State. J Environ Anal Toxicol 7: 519. doi: $10.4172 / 2161-0525.1000519$

Page 4 of 5

p $>0.05$ from the control experiment and also from other analysed samples. Docosane was below detectable limit in Ilisha Africana. Other even aliphatic hydrocarbons like Hexacosane, Triacontane and hexatriacontane were not detected in all the aquatic sample animals. Octacosane were only detected in Mackerel, Barracuda and Needle fish with concentrations of $0.14 \pm 0.24,0.04 \pm 0.01$ and $0.03 \pm 0.01$ $\mathrm{mg} / \mathrm{kg}$ respectively. Odd number aliphatic hydrocarbon like Nonane and Nonadeacne were also detected in the aquatic samples. Nonane attained its highest concentrations in Mackerel and Needle fish with concentrations of $0.19 \pm 0.15$ and $0.011 \pm 0.00 \mathrm{mg} / \mathrm{kg}$ respectively. While Nonane concentrations in Mackerel fish shows significant different at $\mathrm{p}<0.05$ from the control experiment, its concentrations in Needlefish shows no significant variability at $\mathrm{p}>0.05$ from the control experiment. Odd number aliphatic hydrocarbon nonadecane attained its highest concentration in Mackerel and Illisha Africana with concentrations of $0.25 \pm 0.42$ and $0.33 \pm 0.45$ respectively. In all, they shows no significant variability from the control experiment $(\mathrm{p}<0.05)$ and from other analysed aquatic sampled animals. It is obviously seen from the results that the percentage of even chain aliphatic hydrocarbons is higher in proportion than odd chain aliphatic hydrocarbons. Eisler 1987 reported that even chain hydrocarbons are mostly seen in living matter than the odd chain correspondence; on report of the mechanisms, even chain compounds are easily metabolized in pathways of living matter and as such found higher in bio accumulation than the odd chain compounds especially when it concerns petroleum fractions. As reported by Pampanin and Sydnes [16], aliphatic and aromatic hydrocarbons pose a great threat to aquatic animals on bioaccumulations and ultimately to humans (through fish and shellfish consumption), there is a constant need for their determination and quantification around the world. The monitoring of hydrocarbons presence in the aquatic environment is therefore a world-wide activity. Since some of these compounds are well known carcinogens and mutagens. From the analysis, the concentrations of the observed aliphatic hydrocarbons nearly exceed the model given by international union on environmental toxicology as compiled by Pampanins and Sydnes. It is seen that most sources of aliphatic hydrocarbons are crude oils and as regards to fordoes terminals where the aquatic faunas were gotten, anthropogenic activities has posed a great health danger due to continual disposal of crude oils by oil drillers and bunkers into nearby rivers in the area. In all the seven analyzed aquatic fauna samples it is found that an average of eight different aliphatic hydrocarbons were accumulated by the aquatic animal where faunas like Mackerel, Cutlass fish, Barracuda and Tilapia fish accumulates ten of the aliphatic hydrocarbons for the first three samples and nine aliphatic hydrocarbons in tilapia fish. This may be attributed to higher in biodiversity of the said aquatic faunas in the area.

\section{Total petroleum hydrocarbons}

Total petroleum hydrocarbons (TPH) which is the term used to describe a large family of several hundred chemical compounds that originally come from crude oil [17]. In the present study it is seen that the totality of all the hydrocarbons accumulated by the samples used in this experiment is significantly higher in concentrations than the aliphatic hydrocarbons. They were also significantly higher in all the samples when compared with the control experiments. This is also similar with the report issued by the ATSDR, in which they affirms that the totality of petroleum hydrocarbon content in the ecosystem is becoming much outrageous and alarming than any other environmental pollutants. From their given concentrations in the aquatic samples, it is seen that this poses great potential health risk to the aquatic animals and invariably to humans who feeds on sea foods.
TPH attained the highest concentrations in Mackerel and Ilisha Africana fishes with concentrations of $2.15 \pm 0.42$ and $3.64 \pm 0.94 \mathrm{mg} /$ $\mathrm{kg}$ respectively. While its lowest in concentration were seen in millet fish with a concentration of $0.08 \pm 0.01 \mathrm{mg} / \mathrm{kg}$. TAHs attained its highest concentrations in Mackerel and Ilisha fishes with concentrations of 3.46 \pm 0.91 and $1.92 \pm 0.34 \mathrm{mg} / \mathrm{kg}$ respectively. Its lowest in concentrations were seen in Millet fish with a concentration of $0.04 \pm 0.02 \mathrm{mg} / \mathrm{kg}$. The US Department of Health and Human Services on Public Health shows the prevalence of Total Petroleum Hydrocarbon in aquatic animals in published articles. The publication showed that TPH when compared with other petroleum hydrocarbons showed a significant variation in higher order than other contaminants. It is seen that among the sampled aquatic animals, Ilisha Africana and Mackerel have the highest bioaccumulation of petroleum hydrocarbons than all the sampled aquatic faunas. This can be attributed to the evidence of bioavailability and eco favorable species and animals $[18,19]$.

\section{References}

1. Ajiboye OO, Yakubu AF, Adams TE (2011) A review of polycyclic aromatic hydrocarbons and heavy metal contamination of fish from fish farms. Journal of Applied Sciences and Environmental Management 15: 1.

2. Bakke T, Hameedi J, Kimstach V, Macdonald R, Melniko, S, et al. (1998) Petroleum Hydrocarbons. In: Roberts A (ed.). AMAP Assessment Report: Arctic Pollution Issues, pp: 667-668.

3. Antizar-Ladislao B (2009) Polycyclic aromatic hydrocarbons, polychlorinated biphenyls, phthalates and organotins in northern Atlantic Spain's coastal marine sediments. Journal of Environmental Monitoring 11: 85-91.

4. Antizar-Ladislao B (2009) Polycyclic aromatic hydrocarbons, polychlorinated biphenyls, phthalates and organotins in northern Atlantic Spain's coastal marine sediments. Journal of Environmental Monitoring 11: 85-91.

5. Ezemonye LI, Ezemonye NN (2005) Polycyclic aromatic hydrocarbons in surface water and sediments of Niger Delta rivers of Nigeria. J Niger Environ Soc 2: 348-358.

6. Fowler SW, Villeneuve JP, Wyse E, Jupp B, de Mora S (2007) Temporal survey of petroleum hydrocarbons, organochlorinated compounds and heavy metals in benthic marine organisms from Dhofar, southern Oman. Marine Pollution Bulletin 54: 357-367.

7. Ashraf W (2005) Accumulation of heavy metals in kidney and heart tissues of Epinephelus microdon fish from the Arabian Gulf. Environmental Monitoring and Assessment 101: 311-316.

8. Fabacher DL, Baumann PC (1985) Enlarged livers and hepatic microsoma mixed-function oxidase components in tumor-bearing brown bullheads from a chemically contaminated river. Environmental Toxicology and Chemistry 4 703-710.

9. Faksness LG, Grini PG, Daling PS (2004) Partitioning of semi-soluble organic compounds between the water phase and oil droplets in produced water. Marine Pollution Bulletin 48: 731-742.

10. Abu GO, Chikere BO (2006) Cell surface properties of hydrocarbon-utilizing bacterial isolates from Port Harcourt marine environment. Niger J Microbiol 20 809-816.

11. Banat K, Förstner U, Müller G (1974) Experimental mobilization of metals from aquatic sediments by nitrilotriacetic acid. Chemical Geology 14: 199-207.

12. Francioni EL, Wagener AD, Scofield A, Depledge M, Sette CB, et al. (2007) Polycyclic aromatic hydrocarbon in mussel Perna perna from Guanabara Bay Brazil: space-time observations, source investigation and genotoxicity. Sci Tot Environ 372: 515-531.

13. Finch LE, Hillyer MM, Leopold MC (2015) Quantitative analysis of heavy metals in children's toys and jewelry: a multi-instrument, multitechnique exercise in analytical chemistry and public health. Journal of Chemical Education 92: 849854

14. Ashraf W (2005) Accumulation of heavy metals in kidney and heart tissues of Epinephelus microdon fish from the Arabian Gulf. Environmental Monitoring and Assessment 101: 311-316.

15. Agency for Toxic Substance Development and Disease Registry (ATSDR) 
Citation: Oparaji EH, Nweze EJ, Agbo KU, Arinzechukwu EO, Anosike JC, et al. (2017) Estimations of Polycyclic Aliphatic Hydrocarbon and Total Petroleum Hydrocarbon in Aquatic Faunas Found in Foccardos Terminal River in Port Harcourt, Rivers State. J Environ Anal Toxicol 7: 519. doi: $10.4172 / 2161-0525.1000519$

(1998). Documentary on Toxicological Profile of Total Petroleum Hydrocarbon Contaminations. Agency for Toxic Substances And Disease Registry, Division of Toxicoloy and Toxicology Information Branch, Atlanta Georgia.

16. Al-Sayed HA, Mahasneh AM, Al-Saad J (1994) Variations of trace meta concentrations in seawater and pearl oyster Pinctada radiata from Bahrain (Arabian Gulf). Marine Pollution Bulletin 28: 370-374.
17. US Department of Human and Public Health (1999) Toxicological Profile of Total Petroleum Hydrocarbon. Agency for Toxic Substance and Disease Registry, Atlanta Georgia.

18. Anderson JW (1979) An assessment of knowledge concerning the fate and effects of petroleum hydrocarbons in the marine environment. Marine Pollution: Functional Responses, pp: 3-21.

19. Bailey NT (1981) Statistical Methods in Biology. 2nd edn. Cambridge University Press. 